\title{
İmān, Islām, taqwā, kufr, shirk, and nifāq: Definitions, examples and impacts on human life
}

\author{
Md. Mahmudul Hassan \\ Centre for University Requirement Courses (CENURC) \\ International Islamic University Chittagong (IIUC), Bangladesh
}

\begin{abstract}
The Holy Qur'an encompasses the comprehensive code for mankind to live a rewarding life in this world, to rescue from the Jahannam and to enter the Jannah in the Hereafter. İmān, Islām, taqwā, kufr, shirk, and nifāq are, the six significant terms, used in the Noble Qur'an frequently. All of them represent the characteristics of human beings. The possessors of these characters will go to their eternal destination; the Jannah or Jahannam. The Jannah is the aftermath of ìmān, Islam and taqwā. On the other hand, kufr, shirk, and nifāq lead to the Jahannam. This study intends to present the definitions and examples of these six terms according to the Qur'anic statement, and then shed light on the impact of each character on human life quoting the evidence from the Holy Qur'an and the Traditions of the Prophet Muhammad (PBUH). The possessors of these six remarkable terms are entitled successively as mu'min, muslim, muttaqi to be rewarded Jannah and kafir, mushrik, and munāif to be punished in Jahannam.
\end{abstract}

Keywords The Comprehensive code, Eternal destination, Qur'anic terms

Paper type Literature review

\section{Introduction}

Imàn, Isläm, and taqwà are three positive divine instructions whereas, kufr, shirk, and nifäq are three negative characteristics which are strongly prohibited by divine decrees. The Jannah and the Jahannam are two eternal destinations of humanities in the Hereafter. The Jannah is the ultimate desire for all people who believe in the Hereafter. For being rewarded with such a place of eternal happiness a believer is to be a cent percent Muslim thoroughly free of various morbidity such as kufr, shirk, nifäq along with being a muttaqi. There are many people who are known as Muslims without fulfilling the requirement of imann, the basic foundation of Islam. Some of them are involved in shirk and kufr by their perceptions, speeches and activities. Some people

IIUC
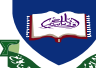

IIUC Studies Vol. 14(2), Dec. 2017 pp. $85-98$ (C) IIUC ISSN 1813-7733 
express their internal taqwa through their external appearance. While some hiding kufr and shirk in their inner self, pretend to be Muslims, and still continue to nourish the dream of becoming one of the dwellers of the Jannah. The study analyzes the definition of imān, Isläm, taqwä, kufr, shirk, and nifäq along with their results in human life.

\section{The definition of $\bar{I} m \bar{a} n$ and its impact}

Imann (الإيمان) is an Arabic word. It means to believe, trust and faith (AlBa'albakī, 1995). Terminologically, it refers to the acceptance of a thing, and to believe it whole heartedly (Al-Gajnawī, 1998). In Islamic view point, iman denotes the belief in all the rules of Allah (SWT) which were revealed to the Prophet Muhammad (PBUH) (Al-Nasuwē, 1414 H.), and to accept them unconditionally by one's own will (Mawdudī, 1996). Therefore, he is a mumin who accepts all rules of Allah (SWT) willingly. Thus imān requires three essential things below (Al-Nasafi, 2012):
a. to believe,
b. to acknowledge and
c. to acknowledge by one's own will

A person, who misses one of above three, cannot be considered as a mumin (Al-Nasafi, 2012). If someone believes, for instance, but does not accept the laws of Allah (SWT) and the way of the Prophet (PBUH), he is not a mu'min. (Al-Fawzān, 2002). Or sometimes though he believes the rules of Allah (SWT) but does not acknowledge them by his own will or accepts by being forced, he too cannot be called a mumin (Al-Jazāirī, (2003). In terms of the holy Qur'an, there are two more important points regarding imān. These are; no commands of Allah (SWT) can be opposed or objected, and no commands of Allah can be hated or disliked (AlFawzān, 2002). Therefore, iman, is clearly related to all these above five points. And if any one of these characteristics is missing then neither can it be termed imàn nor the person concerned can be called a mu'min. For an example: salät is an obligatory 'ibädah. It requires the following five characteristics:
a. To believe salāt as fard.
b. To acknowledge sälat as fard
c. To acknowledge sālat to be fard by one's own will, not by compulsion.
d. Not to oppose salāt to being fard.
e. Not to contempt salāt to being fard 
Thus, if one accepts salat in these ways then in case of salat he is a mumin. Similarly, iman should be understood by maintaining all these five points in every aspect such as in case of sâेm, hajj, and zakat, in speaking truth, not giving or taking bribe, in maintaining hijab, and in other issues. Therefore, here a point is very essential, that is, to be called as a mu'min in terms of the Holy Qur'an, he should confirm these five issues regarding all the rules of Allah (SWT) and the Traditions of the Muhammad (PBUH). According to the statement of the Noble Qur'an his destination is Jannah by the grace of Allah (SW'T). As He said:

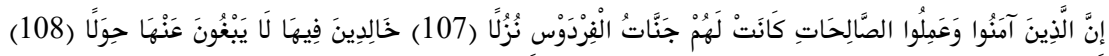

"Verily, those who believe and do righteous deeds shall have the Gardens of Paradise for their entertainment, wherein they will dwell (forever); they will not desire any change therefrom" (Al-Qur'an, 18:107-108).

\section{The definition of Islam and its impact}

For easy understanding of the meaning of Islam we can imagine the following examples:

a. Iman is the foundation of a palace and Islam is the whole structure of that palace.

b. Imān is the soul, Islam is the body.

c. Iman is the root of a tree, Islam is the rest parts of the tree.

d. Iman is an engine of a car, Islam is the rest part of that car.

Thus, without imān, a man cannot be called as a Muslim, and all his contributions towards Islam unfortunately can bring no benefit. In reality, to assume a tree without its root, a palace without a foundation, or a car without an engine is impossible. In the same way, any person, being involved in the activities of Islam without iman, cannot be a Muslim and even will not be rewarded in the Hereafter. Imann, therefore, is the strong and main part of Islam (Mawdudī, 1996).

Islam (الإسلام) is an Arabic word. It means to surrender, to submit or to be obedient (A Bureau of Scholars, 1421H). In terms of the Holy Quran, Islam means to surrender oneself to Allah (SWT) for implementing all the commands and shunning all prohibitions of Allah (SWT) in the method of Muhammad (PBUH), and he is a Muslim who surrenders. Thus, we can say that to believe and to give acknowledgement to anything is called imàn, and to execute that believe is known as Islam. 
a. Just like, salat is a fard act; to believe it is imān, and to perform salät is Islam.

b. Sawm is another a fard act; to believe it is imann, and to observe fasting is Islam.

c. To take bribe is haram; to believe this is iman, and to reject bribe is Islam.

d. To believe all rules of Allah (SWT) in every aspect of life is imān, and to follow them practically is Islam.

Thus, a person is named as Muslim only according to his implementation of Allah's rules. Such as, if he performs his prayer then in respect of salat he is a Muslim, but if in another matter he does not follow the rule of Islam, then here he is not a Muslim.

Allah (SWT) enjoined the mumin to be complete Muslims saying:

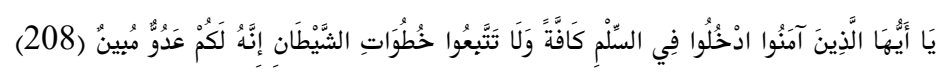

"O believers! Enter perfectly in Islam, and do not follow the footsteps of Satan. Indeed, he is your open enemy" (Al-Qur'an, 2: 208).

That means, the commands and prohibitions of Allah (SWT) should be obeyed by a mu'min in all spheres of life; personal life, family life, social life, national and international life. And obeying them is to have a complete entrance into Islam (Al Razi, 2000). And those who will obey all these commands and prohibitions completely will be an absolute Muslim. Allah (SW') enjoined to strive till death to be a complete Muslim saying:

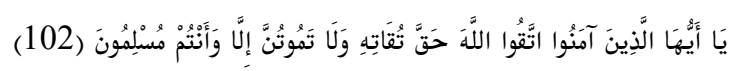

"O believers! Fear Allah as He should be feared and do not die except being complete Muslims" (Al- Qur'an, 3:102).

Allah (SWT) ordered all believers to fear Him and to follow each of His commands and prohibitions. And in this regard the diligent attempt of a mumin will continue till his last breath. And if a person has faith in all the rules conferred by Allah (SWT) and shown by Muhammad (PBUH), and willingly accepts them without disbelieving, hating, rejecting or opposing any of the law, he is a mumin. After this, he will be that percent of Muslim according to his percentage of implementing those rules. If he commits any great sin before his death, such as, consuming alcohol, to take bribe, to do injustice, in short, to do those deeds which Allah (SWT) has prohibited and that he con not repent then for these types of sin he will be punished first. As a result, his destination will be in the hell but 
later on, by the will of the Merciful Allah (SWT) his final abode will be in the heaven (A Bureau of Scholars, 1421H).

\section{The definition of taqwā and its impact}

'Taqwà' (التقوى) is an Arabic word, which means fear of Allah; piety, righteousness and religiousness. In terms of the Qur'an, taqwā means following all the commands of Allah and abstaining oneself from His prohibitions. And the one who fears Allah is called righteous, muttaqi who guards himself against all kinds of sins and harmful things ('Omar, 2010).

There are three stages of taqwā and muttaqī (Al- Baidawi, 1998), they are:

Firstly: fearing Allah (SWT) by following all al-sunnat-al-muakkadah rules after practicing all the mandatory and wajib deeds in Islam. And to refrain oneself from all sorts of prohibited (haram) and al-makrub al-tabrimi activities.

Secondly: fearing Allah (SWT'), by practicing all types of al-sunnat almuakkadah after practicing all the mandatory and wajib issues in Islam. And then to refrain oneself from all sorts of prohibited (haram) and almakrub-al-tabrimi and to save oneself from al-makrub al-tanjibi. At this stage, the righteous becomes closer towards Allah (SWT).

Thirdly: according to the desire of Allah (SWT), all his deeds, thoughts, actions are done and will be rewarded for it. At this level, a righteous is accepted as Allah (SWT)'s close friend. Allah (SWT) said about such friend:

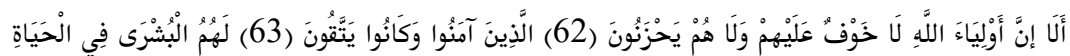

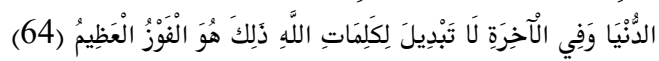

"Behold! Verily the friends of Allah shall certainly have no fear, nor shall they grieve. Those who believed and used to fear Allah much. For them are glad tidings in the present world and in the Hereafter There is no changing in the words of Allah. This is indeed the supreme success" (Al-Qur'an, 10: 62-64).

At this stage, Allah (SWT) blesses the righteous with whatever they pray for. And with the enemies of the righteous Allah (SWT) is enraged (Al-Humaydī, 2002). Without following the mandatory and wājib and without avoiding the prohibited things and al-makruh al-taharimī, calling oneself a close friend of Allah (SWT) is hypocrisy. Moreover, taqwā is not in attire or in name and fame. It is absolutely against taqwā to expect praise, respect, name and fame from people for doing good deeds ('Ibn Bāz, 1413H). Rather taqwā is related to one's intention and mind. Allah (SWT) said: 


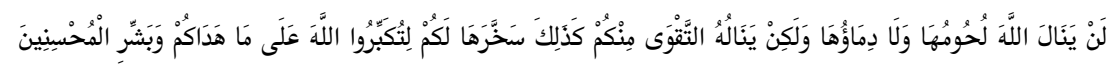

"It is neither their meat nor their blood that reaches. Allah, but it is piety from you that reaches Him..." (Al-Qur'an, 22:37).

According to the statement of the Prophet (PBUH) taqwa is related with one's mind (Al-Basti, 1993). It means that taqwa is to have fear of Allah (SWT) while thinking, doing or not doing any work. In some Muslim territories, people generally think that to have beard and turban for man, wearing hijab for women, etc. are signs of taqwā. In fact all these attires cannot be considered the basic signs of taqwa though these activates are considered a part of shari'ah and by following them one may be rewarded. If a man keeps beard, wears Jubbah, turban and a woman wears hijab, but disbelieves, rejects, hates, or opposes any one of the laws of shari'ah, he and she, instead of being righteous, could be rather called a disbeliever and could not be counted as a mumin even. Allah (SWT) has enjoined the believers to become the truly obedient servant of Allah by reaching to top most level of taqwà saying:

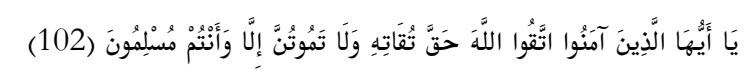

"O ye who believe! Fear Allah as He should be feared..." (Al-Qur'an, 3:102).

A muttaqi will be rewarded the al-Jannah as Allah (SWT) said:

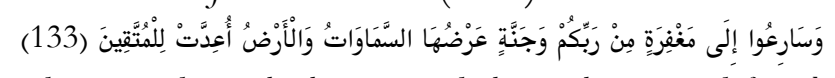

"... And for Paradise as wide as the heavens and the earth, prepared for alMuttaqūn" (Al- Qur'an, 3:133).

\section{The definition of kufr and its impact}

Kufr (الكفر) is a destructive morbidity that harms ones imann. It is an Arabic term which means to cover, hide, and disbelieve (Al-Ba'albaki, 1995). According to the Holy Qur'an, kufr means to disagree, to reject or not to give declaration to any one of the commands and prohibitions bestowed by Allah (SWT) and shown by Muhammad (PBUH). It is completely opposite of imān. The following characteristics ensure kufr (Al-Gajnawī. 1998).
a. To prove a rule of Allah (SWT) as false or to disbelieve it
b. Not to accept willingly and wholeheartedly any a rule of Allah (SW'T)
c. To oppose a rule of Islam
d. To dislike or hate a rule of Allah (SWT)
e. To doubt a rule of Islam 
If anyone of the above mentioned things is done, it will be kufr. And he is a kafir who is involved in any one of these things. These two terms, kufr and Käfir are used with different meanings in the holy Qur'an.

Firstly, in the Holy Qur'an these two terms käfir and kufr have been used many times in the meaning of rejecting any of the rules of Allah (SW'T) shown by Muhammad (PBUH). And rejecting only one of them is similar to reject all other orders of Allah (SWT). There are many verses in this connection: As Allah (SWT) said:

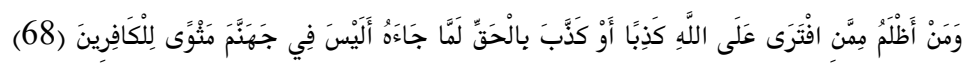

"And who does more wrong than he who invents a lie against Allah, or denies the truth when it comes to bim? Is there not a dwelling in Hell for disbelievers?" (AlQur'an, 29:68).

One who knowingly rejects or tries to prove any one of the rules of Allah (SWT) false is kafir. Secondly, in the Holy Qur'an, the words kufr and kajfir were used when any single rule of Allah (SW'T) is believed but not acknowledged. And if one believes and acknowledges all the orders except one which he denies, it is as similar to deny all the orders (AlHakmi, 1990). There were many disbelievers such as Abu Jabl who believed Muhammad (PBUH) and also believed that all the rules revealed were true and from Allah (SWT). But they did not acknowledge Muhammad (PBUH) and Islam only because of their greed for worldly pleasure and power to dominate. As Allah (SWT) said:

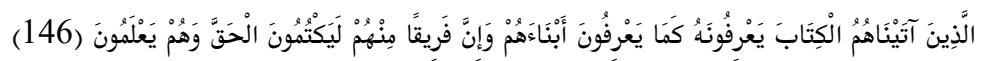

"Those to whom We have given the Book recognize it even as they recognize their sons, but surely some of them conceal the truth knowingly" (Al-Qur'an, 2:146).

Thirdly, in the Holy Quran, the word 'kufr' is used in the case of hating or opposing a rule of Allah (SWT). Similarly, it is same to oppose all the rules inscribed in the Quran just by hating or opposing any one of the rules out of pride though accepting all the other rules. For instance, the Satan, Iblis opposed to Allah (SW'T) in prostrating Adam (A) by abhorring the decree (Al-Tabari, 2000). There are ample verses of the Holy Qur'an regarding this issue as Allah (SWT) said:

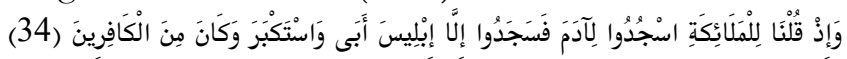

"And remember the time when We said to the angels: Prostrate yourselves before Adam', and they prostrated except Iblis (Satan), he refused and was proud and was one of the disbelievers" (Al-Qur'an, 2:34). 
Satan committed only one sin and he proudly denied only one order of Allah (SWT). He tried to give explanation for his disobeying the order of Allah (SWT) and thus became a käfir (an infidel). Regarding this Allah (SWT) said:

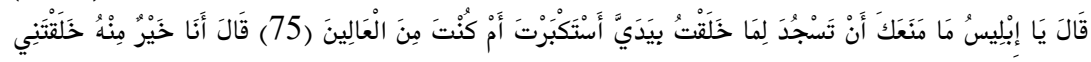

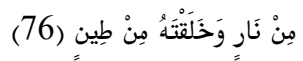

"O Iblis, what prevents you from prostrating yourself to one whom I have created with Both My Hands. Are you too proud (to fall prostrate to Adam) or are you one of the high exalted?" (Al-Qur'an, 38:75-76).

The effect of kufr is very bad and the punishment of a kaffir is grievous. A remarkable verse from numerous verses regarding the aftermath of kufr and the punishment of a kajfir is as follows:

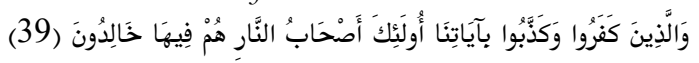

"But those who disbelieve and believe Our ayats, such are the dwellers of the Fire; they shall abide therein forever" (Al-Qur'an, 2:39).

\section{The definition of shirk and its impact}

Shirk (الثرك) ), a dangerous virus which appears as an obstacle in the successful way of iman and Islam. It is an Arabic word which means polytheism (Al-Ba'albaki, 1995). As a term of Qur'an, shirk means to associate anything else with Allah (SWT) or with His Attributes. And the one who ascribes with Allah (SWT) is a mushrik (a polytheist) (Salmān, 2002).

Shirk is of two types; al-shirk al-akbar and al-shirk al-asgar (Al-Fawzān, 2002). Al-shirk al-akbar is such a dangerous malady that excludes mushriks from the mumins (Al-Fawjan, 2002). These mushriks if do not return back to imān, and Islam by seeking repentance from Allah (SWT), their eternal abode in the Hereafter will be in Jahannam. Some examples of such type of shirk are:

a. To worship any person or anything besides Allah (SWT).

b. To sacrifice or to make any vow in the name of any person or living thing besides Allah (SWT).

c. To believe that besides Allah (SWT) any person also can help or harm.

d. To believe that besides Allah (SWT) other things can also fulfill any wish.

e. To believe that besides the law of Allah (SWT) some other laws can also be followed in every aspect of life.

f. To believe that someone else besides Allah (SWT) can give life and death. 
g. To believe that someone else besides Allah (SWT) can provide livelihood.

h. To believe that someone else besides Allah (SWT) can give son or daughter.

i. To believe that someone else besides Allah (SWT) knows about the future.

j. To believe that someone else besides Allah (SWT) can change ones fate and so on.

All the above thoughts, words and actions are included in this type of shirk which destroys one's imān, along with all his good deeds. Regarding this type of thoughts and actions Allah (SWT) said:

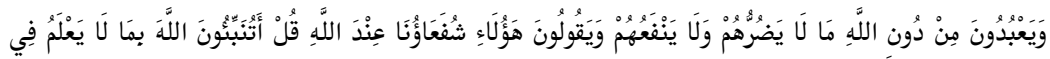

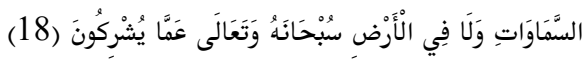

"And they worship, instead of Allah, that which neither harms them nor profits them; and they say, 'These are our intercessors with Allah.' Say, 'Do you inform Allah of that which He knows not in the heavens or in the earth?' He is immaculate and exalted over whatever they associate with Him" (Al- Qur'an, 10:18).

The Lord is the one who is creator of everything, who rules over everything, who is able to fulfill every wish, who is a rescuer of every trouble, who is the provider of life and death, etc. And all these things are not under the control of any creature, such as men, jinn, angels, tree, fire, water or animals. Allah (SW'T) is the Creator of every creature, the Owner of everything and the Sustainer of everyone. (Salmān 2002). There are many verses of the Holy Qur'an which were revealed narrating this issue. As Allah (SWT) said:

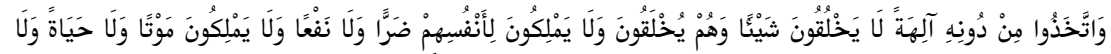

$$
\text { نُشُورًا (3) }
$$

"Yet they have taken besides Him other gods, who create nothing but are themselves created, and who have no power to harm or benefit themselves and they control not death nor life nor resurrection" (Al-Quran, 25:3).

Things such as idols, tree-plants, graves, shrines, angels, prophets, and a pious person all are included under these features. They have no power to create anything and one but Allah (SWT) is the only Creator of everything. Therefore, it is shirk to invoke these things in any need instead of Allah (SWT) (Al-Fawzān, 2002). There are ample ayats in the Qur'an 
that have proclaimed the association of Allah (SWT) with other things as irrational, false and injustice (Al-Fawzān, 2002). This type of malady destroys the imān, and in this stage, after committing such sin, if any one dies without repenting, his eternal abode will be in the Hell- Jabannam.

Al- shirk al-asgar does not destroy the imann of a Muslim directly but slowly it reduces one's faith in the Oneness of Allah (SW'T). And this will turn into a great shirk if they are let continue for a long time. As a result, it will destroy the good deeds of a mumàn (Al-Fawzān, 2002). These are again of two types: disclosed that can be seen and undisclosed that cannot be seen. The disclosed sins are while speaking or doing anything and in case of intention it is concealed sin. Shirk in case of speaking is like:

a. "I could not have saved if Allah and you have not helped".

b. "The doctor had cured my disease".

c. "First on Allah then on you I trust for saving my son" etc.

All these types of remarks are accounted as minor shirk which could lead any person to commit major sin. The second type of al-shirk al-asgar is concealed or secret shirk. This type of shirk is related with one's wish and intention. That is, to do things which could satisfy Allah (SWT) but are done with the desire to be praised by other persons such as:

a. By giving charity people will call generous man.

b. People will address as al-hajj if the hajj is performed.

c. By wearing jubbah, turban and keeping beard, people will know as pious so on.

But if all these are done with the intention only to satisfy Allah (SWT) without anticipating any praise from any person, it won't be shirk and does not matter if people praise him or not. Every action should be done only to satisfy Allah (SW'T).

\section{The definition of nifāq and its impact}

Nifäq (النفاق) is an Arabic word which means hypocrisy, duplicity, to hide and double dealing (Al-Ba'albaki, 1995). Terminologically, it means to express exactly the opposite to what is in his mind (Al-Fawzān, 2002). For example, if a person dislikes another one, but expresses that he loves him. In terms of the Holy Qur'an, it refers to show off that one believes, accepts, likes and agrees with any of the rules of Islam but actually he disbelieves, hates, rejects and opposes that rule entirely or partially (Ibn Hajam, 1996). And the person with such type of characteristic is termed as munafiq (a hypocrite) in the Holy Qur'an. For instance, following rules of hijab is mandatory and the characteristic of a hypocrite is in this issue: 
a. He internally disbelieves hijab to be mandatory but externally expresses that he believes it to be so.

b. He does not accept hijab to be mandatory though he believes in it. But externally he expresses to acknowledge it to be mandatory.

c. Inwardly he dislikes hijab but does not convey it.

d. He opposes hijab whenever he gets any chance and internally but externally he always is in the support of hijab.

Therefore, if any of these above four characteristics are found in a man at the time of following the law of Allah (SWT) in all his activates, he is tagged as hypocrite (Al-Iyjī, 1997; Al-Fawzān, 2002). Allah (SWT') revealed 13 ayats $\left(8^{\text {th }}-20^{\text {th }}\right)$ of surah al-Baqarah describing the characteristics of such hypocrites. A disbeliever expresses ' $k u f r$ ' directly whereas hypocrite conceals it and pretends Islam (Al-Lālkāē, 1402H).

There is another type of hypocrites such as those who are with imān. They have no weakness regarding belief in the law of Allah (SWT). They believe in all the rules and accept them without hating or opposing but take the help of some tricks when it comes to put into practice. Some of the characteristics of such type of hypocrites are as follows:

a. They speak lie

b. They break the promise

c. They betray amānat

d. They do not perform their salat in congregation especially in the Fajr salāt etc

A true mu'min always attempts to keep himself away from such awful characteristics of a hypocrite. If a person pretend to believe, accept, like the rules of Allah (SWT) which is shown by Muhammad (PBUH), but internally he disbelieves, rejects, or hates any one of the law then he is a hypocrite without imān. If death comes at this stage then surely his final abode will be in the hell. As Allah (SWT) said:

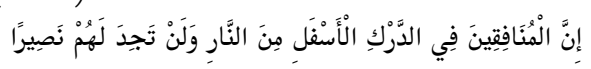

"Verily, the hypocrites will be in the lowest depth (grade) of the Fire; no helper you will find for them" (Al-Qur'an, 4:145).

\section{Conclusion}

Finally, the study has investigated the following points;

- Allah (SWT) sent mankind to this world as His representatives for a short period of time. The purpose of the creation of mankind is that man will believe in each and every command and prohibition of Allah (SWT) and accordingly, will follow them in every aspect of life. 
- $\quad$ Allah (SWT) bestowed men their freedom to accept or else to reject the rules of Allah (SW'T).

- Imān, Islām, taqwā, kufr, shirk, and nifāq are remarkable terms used in the Holy Qur'an. And the possessors of them are entitled successively as mu'min, muslim, muttaqì, kafir, mushrik, and munäfiq,

- Mu'min, muslim, muttaqi, will be rewarded Jannah- an eternal abode, by Allah (SWT) and kafir, mushrik, and munafiq, will be compelled to be punished in Jahannam.

- Allah (SWT) revealed ample of ayats encouraging His servants to be rewarded, and warning them of punishment.

- Above all, one should keep in one's mind that, it is to the intent of Allah (SWT) to decide Jannah or Jahannam for His servants.

\section{Notes}

1. Al-Jannah: Garden that is a common Qur'anic name for Paradise (firdaws), the place of reward for the deceased Muslim (Gordon, 2002).

2. Al-Makrūh al-Tahrīmī: The matter which is nearly unlawful (AlKhudrawī, 2004).

3. Al-Makrūh al-Tanjīhī: The act which approaches the lawful (AlKhudrawī, 2004).

4. Al-Sunnat al-Muakkadah: Emphasized sunnah. A practice of the Prophet (PBUH) that was emphasized by him through his meticulous observance of doing it (Saleh, 2011).

5. Fard: Religious duty. It has two types; fard 'ayn that is incumbent on each individual such as saying daily prayer, observing saŵm etc., and fard kifāyah that is incumbent on the community like performing funeral prayer (Gordon, 2002).

6. Hajj: The pilgrimage rite to Mecca, one of the essential pillars of Islam required of Muslims once in their lifetime, who are able to perform (Martin, 2004).

7. Halal: Permissible which is used for lawful things and activities (Campo, 2009).

8. Haram: Forbidden act in Islamic law, such as the consumption of pork and alcohol are haram (Martin, 2004).

9. Ibadah: Devotional acts of worship (Martin, 2004).

10. Jahannam: It is mentioned frequently in the Qur'an, and is used either for Hell generally or for one of the seven ranks of Hell. It is a synonym of an-Nār, the fire (Gordon, 2002). 
11. Salat: It is one of the pillars of Muslim devotional life. Muslim pray five times a day (Martin, 2004).

12. Sawm: It means fasting. For Muslims a fast from sexual intercourse, food and liquids take place from daybreak to sunset (Safra, 2006).

13. Shari'ah: It means 'Islamic law". The Qur'an and the traditions of the Prophet (PBUH) are the basis for scholars and judges to determine Shari'a (Martin, 2004).

14. Wajib: It means an essential duty. In Islamic law it occupies the position after fard (Adamec, 2009).

\section{References}

A Bureau of Scholars. (1421H.). Kitäbu Usūl al-İman. Medina, KSA: Maktabatu alMalik Fahad.

Adamec, L. W. (2009). Historical Dictionary of Islam (2 ${ }^{\text {nd }}$ ed.). Maryland, USA: The Scarecrow Press.

Al-Baidawī, A. (1998). Anwār al-Tanjill, wa Asrär al-Täwīl. Beirut, Lebanon: Dar Ehya al-Tourath al-Arabi.

Al-Bastī, M. (1993). Sabēh ibn Hibbān (2nd ed.). Beirut, Lebanon: Muassassa alRisalah.

Al-Fawzān, S. (2002). I'yānatul Mustafid bi-Sharbi Kitāb al-Tawhēd (3rd ed.). Beirut, Lebanon: Muassassa al-Risalah.

Al-Gajnawī, A. (1998). Kitäb Usul al-Dèn (1st ed.). Beirut, Lebanon: Darul Bashayr Al Islamia.

Al-Hakmi, H. (1990). Ma'ärij al-Qobul (1 ${ }^{\text {st }}$ ed.). Dammam, KSA: Daru Ibn alQayuum.

Al-Humadī, M. (2002). Al-Jam'u Bayna al-Sahihain (2 ${ }^{\text {nd }}$ ed.). Beirut, Lebanon: Dar al-Nashar.

Al-Īyji, A. A. R. (1997). Kitāb al Mawäqif (1 ${ }^{\text {st }}$ ed.). Beirut, Lebanon: Dar al Jayl.

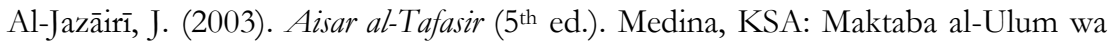
al-Hikam.

Al-Khudrawī, D. (2004). Dictionary of Islamic Terms. Beirut, Lebanon: Al-Yamamah.

Al-Koda'ī, M. (1986). Musnad As-shihäb (2nd ed.). Beirut, Lebanon: Muassasa alRisalah.

Al-Lālkāè, H. (1402H). Sharbì Usuli I'tiqādi Abli al-Sunnah. Riyadh, KSA: Daru Tibah. 


\section{IIUC Studies, 14(2)}

Al-Nasafi, U. (2012). Sharbu al-'Aaquid al-Nasafyyah. Karachi, Pakistan: Maktabat al-Madanyyah.

Al-Nasuwē, (1414H). Abul Abbas al-Hasan bin Sufian, Al-Arba'in (1 ${ }^{\text {st }}$ ed.). Beirut, Lebanon: Dar al-Bashair al-Islamyyah.

Al-Razi, F. M. (2000). Mafätīhu al-Ghayb. Beirut, Lebanon: Dar al-kutub al Ilmiyyah.

Al-Tabari, M. (2000). Jämi'a al-Bayan fì Tâwil al-Qur'an (1 ${ }^{\text {st }}$ ed.). Beirut, Lebanon: Muassasa al-Risalah.

Al-Ba'albaki D. R. (1995). Al-Mawrid (7th ed.). Beirut, Lebanon: Dar al- 'Ilm li al Malayin.

Campo, J. E. (ed.) (2009). Encyclopedia of world religions, encyclopedia of Islam. New York, USA: Gordon Melton, series Editor, Facts on File, Inc.

'Ibn Bāz, A. A. (1413H). Fatawā Mubimma li Umumi al-Ummah (1 ${ }^{\text {st }}$ ed.). Riyadh, KSA: Dar al-Asima.

Martin, R. C. (ed.) (2004). Encyclopedia of Islam and the Muslim World. New York, USA: Macmillan.

Mawdudī, A. 'A. (1996). Islamic Way of Life. Batha, KSA: King Fahd National Library.

Gordon, D. (2002). A concise encyclopedia of Islam. Oxford, England: One World Publications.

'Omar,' A. M. (2010). Dictionary of the Holy Qur'an. China: Noor Foundation.

Safra, J. E. (2006). Britannica, Encyclopedia of World Religions. Chicago, USA: Encyclopedia Britannica.

Saleh, M. I. (2011). Dictionary of Islamic words and expressions. Riyadh, KSA: Maktaba Dar-us-Salam.

Salmān (2002). Taisì al-'Až̃z al-Hamid (1 ${ }^{\text {st }}$ ed.). Beirut, Lebanon: Al- Maktab alIslami.

\section{Corresponding author:}

Md. Mahmudul Hassan can be contacted at: mahmudulhassan1184@yahoo.com 